\title{
Latent heat thermal energy storage systems in lightweight construction: review of PCM applications in Solar Decathlon houses
}

\author{
E. Rodríguez-Ubiñas, L. Ruíz-Valero, S. V. Sánchez \\ \& F. J. Neila González \\ Department of Building Technology, School of Architecture, \\ Technical University of Madrid, Spain
}

\begin{abstract}
The use of thermal mass in buildings is an effective way to improve the building's interior comfort in places with high diurnal temperature variation. Combined with other passive strategies, thermal mass can play an important role in the energy efficiency of the building, minimizing the necessity of the traditional conditioning systems. However contemporary construction tends to industrializing light weight systems with low thermal mass. An innovative way to add the thermal mass' benefits to the buildings is the use of the latent heat thermal storage capacity of the Phase Change Materials (PCM). In the Solar Decathlon, solar houses competition organized by the United States Department of Energy. The houses are tested and monitored in Washington DC, where the use of short term thermal storage systems is adequate to maintain the interior comfort and reduce energy consumption, therefore many teams had incorporated PCM in theirs industrialized lightweight houses. In this paper the solutions on the application of PCM used in this competition are discussed.
\end{abstract}

Keywords: PCM, latent heat, energy storage, solar decathlon, TES.

\section{Introduction}

Solar Decathlon (SD) is a biennial international competition and public event organized by the U.S. Department of Energy's, in which 20 university teams from around the world compete to design, build, and operate solar-powered houses that are cost-effective, energy-efficient, and attractive $[1,2]$. The SD 
houses should be transported from the universities sites and assemble in only six days in the National Mall in Washington DC. For that reason the teams develop lightweight and highly industrialized prototypes. The main disadvantage of this kind of construction is their low thermal mass, which causes them to have large temperature fluctuations follow the external cooling or heating loads [3]. Adding thermal mass to SD houses is an effective way of reducing its heating and cooling load especially in a location with large daily temperature variation, as Washington DC [4].

The major advantages of the Phase Change Materials (PCM) are their large heat storage capacity and their isothermal behaviour during the charging and discharging process [5]. That mean that PCM performs similar to the traditional thermal mass materials, but they are lighter, more flexible and compact, with greater capacity for heat storage and with specific heat phase change temperatures, that permits to select optimum set point.

Knowing PCM characteristics and its compatibility with the industrialized lightweight construction, participant teams, had developed or applied innovative latent heat thermal storage systems using these materials. The present study includes all SD houses that in their documentation or in the competition prototypes have latent heat thermal energy storage systems.

\section{Study description and classification of PCM applications}

The SD houses PCM applications have been studied and classified into four main aspects: the first relating to the PCM location, the second to the type of system, the third to the type of PCM and its encapsulation and the fourth relating to support strategies.

\subsection{PCM location}

Baggs and Mortensen [6] in their design guide suggest that the best place for thermal mass is the floor, where it is possible to take advantage of direct solar gain through the glazing. And the next preference locations are the interior partition and the internal skin of external insulated walls. The PCM could be located in any place of the building depending on the purpose [5, 7], four locations have been identified in this study: floor, wall (internal skin), ceiling and furniture.

\subsection{System types}

Heating and cooling PCM systems are classified in passive and actives. Passive when no mechanical or active systems are used; and active when fans or pumping mechanisms are used to move or re-circulated air or liquids.

\subsection{PCM and its encapsulation}

The type of PCM selection is primarily linked to the melting temperature required. In the case of buildings thermal conditioning with temperature ranges 
between $20^{\circ}$ and $30^{\circ} \mathrm{C}$, salt hydrates, paraffin and fatty acids can be used. The salt hydrates, or eutectic mixtures of salt hydrates, are inorganic salts with water of crystallization, while the paraffin (hydrocarbon compounds) and the fatty acid are organic substances. All these PCM change from solid to liquid and vice versa, so they need to be encapsulated or integrated in a matrix to prevent leakage. There are a large variety of encapsulating systems with very different sizes, geometries and materials. The micro-encapsulation has greatly expanded the PCM integration possibilities in building materials and systems [5, 7].

\subsection{Support strategies}

PCM, as the thermal mass, can substantially reduce the use in active heating and cooling systems when is correctly used and combined with passive and semipassive design strategies. As an example, several studies have shown that thermal mass together with night ventilation may reduce the indoor maximum temperature, by $2^{\circ}-6^{\circ} \mathrm{C}[8,9]$. The passive strategies permit to take advance of the environmental conditions and resources, and the actives elements could accelerate heat exchange across the surface of the PCM or help to complete their charge-discharge cycles. Some support strategies are: direct and indirect sun gains, natural ventilation, night radiation and free-cooling [10].

\section{Solar Decathlon houses}

The Case Studies are present follow the first two elements of study: Location of PCM and Type of System. And each house description includes the main elements of the systems, the PCM type, its encapsulation type, the passive or semi-passive strategies used and the functioning in cooling and heating mode.

\subsection{Floor application}

\subsubsection{Floor application: passive systems}

Ontario/BC House (2009). The system designed by the Ontario team consists on macro-encapsulated PCM embedded in the floor assembly, underneath the engineered hardwood flooring (see Fig. 1a). The team used a commercial PCM, DELTA-COOL 21. The Delta-Cool system consists on salt hydrate PCM encapsulated in $15 \mathrm{~mm}$ thick polypropylene panels. This PCM is engineered to melt at $24^{\circ} \mathrm{C}$ and solidify at $22^{\circ} \mathrm{C}$ and each panel has an approximate heat storage capacity of $62.6 \mathrm{kWh}$. A total of $62.1 \mathrm{~m}^{2}$ of PCM panels where installed, with a latent heat capacity of $158 \mathrm{~kJ} / \mathrm{kg}$ [11].

In winter days the PCM absorbs the thermal energy directly from the sunlight falling on the floor, and in summer the PCM reduces the peak cooling load by taking off the excess heat during the day and releasing it at night when it can be ventilated away by cool night air. Building energy simulations predicted that the house active shading, its glazing and the PCM system could effectively eliminate cooling loads and reduce heating loads to $45 \%$, while also providing ample daylight and reducing the need for artificial light while the sun is out $[12,13]$. 


\subsubsection{Floor application: active systems}

Canadian Solar House (2005). This house has a Tromble wall and an active thermal energy storage system, designed by the team, based on PCM-soaked ceramic bricks placed in $7 \mathrm{~cm}$ cavities under the floor finishing. Ordinary bricks were dipped on a mix of PCM, $48 \%$ butyl stearate $50 \%$ propyl palmitate $2 \%$ fat acid [14]. The hot air passing behind the house $\mathrm{PV} / \mathrm{T}$ system is used to pre-heat domestic hot water, to improve the heat pump efficiency and to storage heat at PCM floor system. In cooling situation, the night cool air is drawing through the brick-PCM storage system in order to reduce the cooling load the following day. In heating situation, the house is heated by the direct solar gains, the effect of the Tromble wall and the warm air of the PV/Thermal panels. In specific moment when the semi-passive system is not enough to maintain the house in comfort, the warn air from the PV is used as the heat source of the heat pump in order to increase the coefficient of performance.

UPM -Technical University of Madrid (2005). The Madrid Team placed its active PCM system in the raised floor plenum. A eutectic hydrocarbon mix gel was encapsulated in blow molded HDPE containers. They also filled the raised floor tiles with PCM to take advantage of the direct sun radiation. (See Fig. 1b.) The system could work as passive one, but forced air improves the thermal exchange and increases efficacy of the system [15]. The house automation system controls periods when the fans must operates, the direction of the air flow as well as the opening of house windows for cross ventilation and the activation of the peltier dehumidification system [16]. In the winter days, the gels melt (storage heat) by direct solar gain of the south glazing façade and by interior warn air recirculation. This heat is released later, helping to maintain the house in comfort even when sun is not present. In summer, cool night air is force to circulate in the floor plenum solidifying the PCM gels and during the day the PCM acts as a heat sink which absorbs the heat excess, minimizing the house overheating [16].

Rhode Island School of Design (2005). This house has two thermal energy storage "boxes", the hot and the cold, both connected to the house radiant ceiling panels. In each box there are blow molded HDPE containers filled with eutectic base solution (PCM) and copper pipes circuits for water recirculation. (See Fig. 1c.) The copper piping array use thick aluminum heat transfer plates to give heat to the PCMs for storage, and to take it back when needed. In heating mode, solar thermal energy is storage in the PCM hot box during the day for usage at night or very cloudy weather, the system draws heat back off the PCMs and uses it to

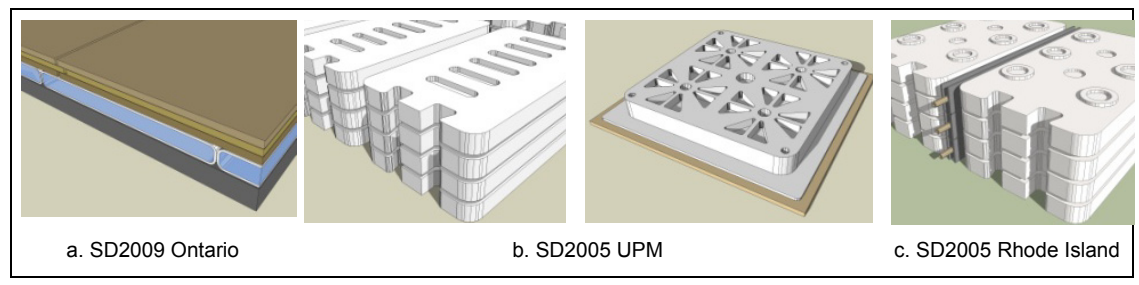

Figure 1: $\quad$ Floor systems. 
heat the house. And in cooling mode, night cool air discharges the PCM that perform as a heat sink to remove the heat excess and help to maintain the house cool. It is a very efficient system; just require energy for small hydronic variable speed pumping system [17].

UPM - Technical University of Madrid (2007). This house was designed making use of the advantages of the systems of Madrid 2005 house and trying to improve some elements of the previous proposals. In the floor plenum were place "thermal batteries" using gel type eutectic mix PCM, but instead of HDPE containers, they design a multi-tubes encapsulation to improve the PCM rates of charging and discharging of energy [18]. The interior pipes are for water recirculation and the exteriors are filled with PCM. The metal encapsulation improves the thermal conductivity of the system and the tubular shape increases the exchange surface. In heating mode, during the day the direct sun contribution is used (air circulation) to heat the house, as well as, the surplus of heat water produced by the solar thermal panels is used to heat the house and to store heat in the thermal batteries. When cooling is necessary, the night refrigeration (air circulation) and the night radiation (water circulation) are used to solidify the PCM and to prepare them to extract the heat of the following day. The water and air recirculation permits take advance of the removable energy resources and ensure the correct charge and discharge of the PCM [19]. (The system was not installed in the competition prototype.)

\subsection{Walls applications}

\subsection{Walls application: passive systems}

Kansas Project Solar House (2007). The system consists of the PCM incorporation in Structural Insulated Panels (SIP). The SIPs are composite building materials that consist of an insulating layer of rigid polymer foam sandwiched between two layers of structural board. The PCM is encapsulated in pipes that are placed in the interior of the insulation layer (see Fig. 2a). With these panels the team constructed both the walls and the roof of the house. This new system, like many others of the Solar Decathlon, has been patented [20].

Penn State (2009). In this house was installed a storage solution developed by Phase Change Energy Solutions, Inc. (PCES), named ThermaMat. The PCM used is obtained from a residue of biodiesel called BioPCM $23^{\circ} \mathrm{C}$ [21]. This PCM is encapsulated in a pouched mat (see Fig. 2b). The encapsulation material is a polyfilm with flame retardant properties. The mats were placed between the walls framing studs directly behind standard plasterboard [22]. This solution was also used in the ceiling.

Team Germany (2009). This Germany house, as it predecessor in 2007, uses micro-encapsulated PCM technology integrated in drywall panels [23]. Their used SmartBoard panels a commercial product of Knauf. These gypsum boards contain Micronal microscopic polymer spheres $(2$ to $20 \mathrm{mc}$ ) filled with paraffin wax developed by BASF. The micro encapsulation permits an effective integration of PCM in the construction materials and improved the convection 
heat transfer by increasing the exchange surface [18]. This house also has an active PCM system at ceiling, see detail on section 3.5.2.

\subsection{Walls application: active systems}

Massachusetts Dartmouth (2005). This house was equipped modular PCM thermal storage panels, designed to fit between the studs. They used 24 Enerphase panels, molded black polyethylene modules $(36 \times 56 \times 5 \mathrm{~cm})$ filled with Calsium Chloride Hexahydrate TESC-81, with phase changing at is $27^{\circ} \mathrm{C}$. Enerphase panels were one of the first PCM products for building thermal comfort in the market, Dow Chemical (See Fig. 2c). The panels were placed inner the south wall and under the windows. The house was equipped with a smart control system and used a combination of forced-air heat exchange, passing intake air by the phase change material to improve the efficacy of the thermal storage system.

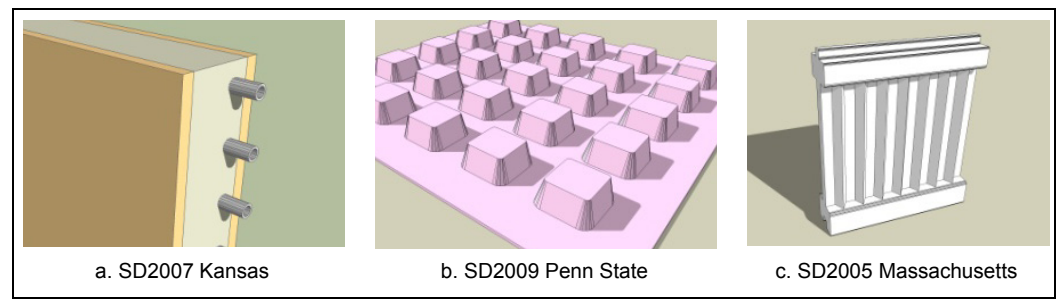

Figure 2: Wall systems.

\subsection{Ceiling applications}

\subsubsection{Ceiling applications: passive systems}

Spain Team (2009). The Spain Team placed Energain, PCM reflective panels, behind the ceiling finishing. This is the first time that Energain panels are used in the Competition [24]. This panels are a mixture of ethylene based polymer (40\%) designed by DuPont and paraffin wax PCM (60\%) laminated on both sides with a $130 \mu \mathrm{m}$ aluminum sheet [25]. This panel has a double function, thermal energy storage (PCM) and a reflective radiation barrier (aluminum) that help to maintain the heat in the house interior. (See Fig 3a.)

\subsubsection{Ceiling applications: active systems}

Technische Universitat Darmstadt (2007). This is the first house that has used micro-encapsulated PCM in the SD. The team used Smartboard, commercial gypsum boards of Knauf, with a radiant ceiling manufactures for Ilkazell (see Fig. 3b). In winter conditions, the solar thermal collector hot water is piped from the hot water tank to the PCM radiant system maintaining the houses interior in comfort. During the summer day cold water is piped from the cold water tank through the PCM radiant ceiling, cooling the house. At summer 
night, heated water is piped onto the roof PV panels to an evaporative heat loss, once cooled is piped back to the cold water tank [26].

Team Germany (2009). In addition to PCM drywalls, this team designed an active system that was placed in four $11 \mathrm{~m}$ long "canals" with a section of $25 \mathrm{~cm}$ x $35 \mathrm{~cm}$, insulated with 1-cm-vacuum panels. Each canal is filled with PCM (salt-hydrate) encapsulate in polycarbonate profile, and are equipped with a ventilation fan, grilles and temperature sensors. The PCM used is Delta Cool 28 by Dorken [23]. (See Fig. 3c.) The system can be regulated due it is in separated zone, different to the house interior, and the variable speed built-in fans and the ventilation flaps which allow operated with either interior or exterior air. The system capacity is equivalent to the energy demand for one day of cooling and its coefficient of performance varies from 9 to 15 depend on the ambient conditions. In cooling mode, during the day mode the interior air circulates through the ceiling and decreases it's temperature, and in night mode the cool exterior air blows through the ceiling and discharges the PCM. [27, 28].

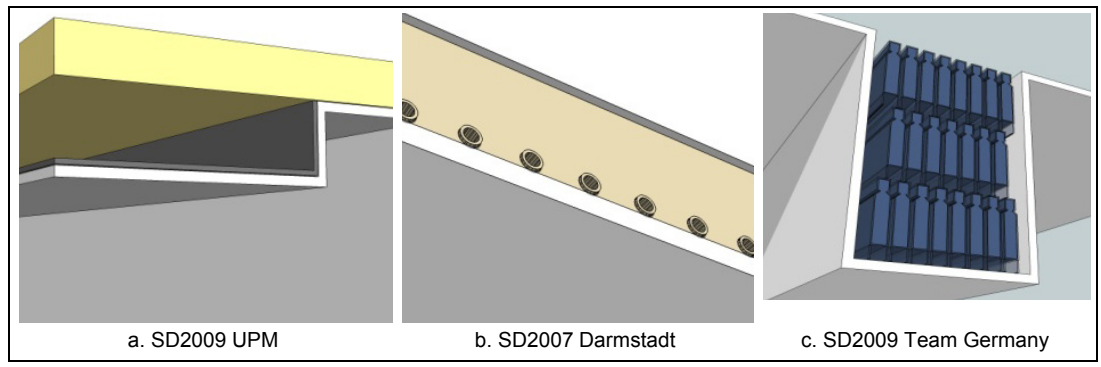

Figure 3: Ceiling systems.

\subsection{Furniture applications}

\subsubsection{Furniture applications: active systems}

UPM - Technical University of Madrid (2007). The Madrid Team, in addition of the under floor thermal storage system, developed an active system to be placed underneath of the furniture, on its bases. For its houses the system was designed to be located in the bases of the beds and living room furniture. The Box-type design of the furniture facilitates to incorporate grates, fans and macroencapsulated eutectic mix gel PCM [29]. (The system was not installed in the competition prototype.)

\subsection{PCM application recap}

Fig. 4 summarizes the latent heat thermal storage applications of the American Solar Decathlon houses, indicating the location, the system type and a brief description system including the PCM used. 


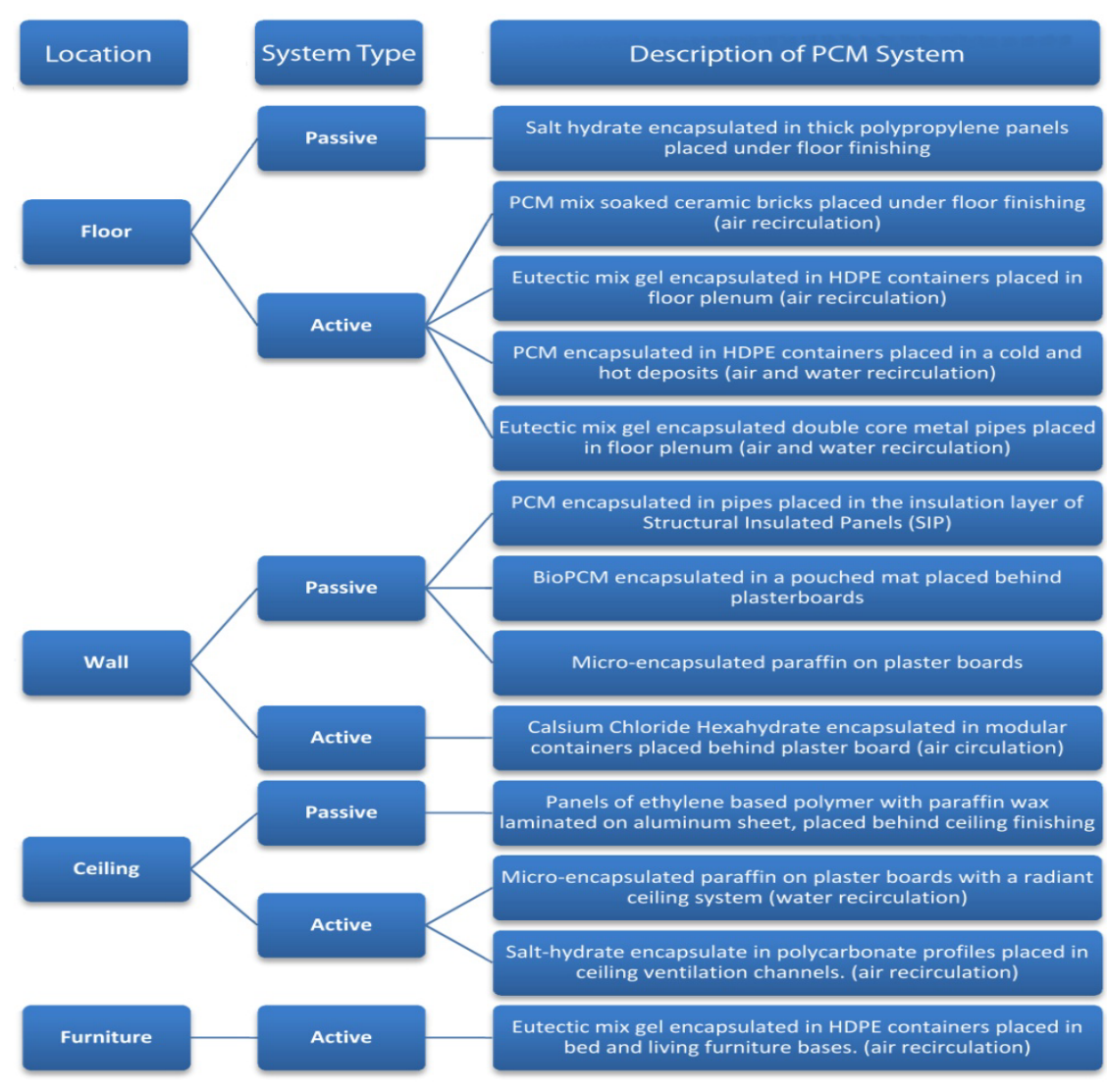

Figure 4: $\quad$ PCM applications in the SD.

\section{Discussion}

\subsection{PCM location}

Floor Passive. Applications used in the floor are related to the location of traditional thermal mass, which trying to take advantage of direct solar gain through the glazing, this is the case with teams of Ontario / BC (2009) and raised floor slabs UPM Team (2005).

Floor Active. Three of the four PCM applications on 2005 were active floor systems. The Canadian and the UPM teams installed fans to accelerate heat exchange by increasing the air movement across the surface of the PCM. The Rhode Island team used the same macro-encapsulation that UPM, but its system has two independent deposits (cold and hot) and a cooper pipes circuits with water re-circulation. UPM in 2007 designed the last floor active system presented in the completion, which use air and water recirculation. 
Wall and Ceiling Passive. The four different solutions present could be used for wall, interior partitions or ceiling. Three fit in custom lightweight multilayer construction: Smartboard (Darmstadt), Energain (UPM) and BioPCM (Penn State). All three are easily integrated, the Smartboard is a gypsum panel that is placed as to traditional ones, and the Energain, reflective panels, and BioPCM, blankets are easily placed just behind the drywall. The fourth was present by Kansas team and linked is to a patent of Sandwich Insulated Panel with PCM.

Wall Active. Only one active system was presented at wall. The Massachusetts team designed with force air recirculation to improve the heat exchanger taking advantage of the south windows hot air.

Ceiling Active. The two ceiling active systems have been presented by the Germany teams. Their 2007 house radiant ceiling that incorporate drywall with PCM. The 2009 house present an application that looks as an evolution of the floor active system that UPM presented in 2005, big deposits with macroencapsulated PCM with air re-circulation.

Furniture. But no many furniture solutions have been proposed for improved the interior space temperature, one of this was the office furniture, PlusICE, was developed in 2005 by UK based company EPS Ltd in collaboration with Climator which incorporate the PCM in a passive way. The solution proposed by the UPM team in 2007 was a compact active PCM system integrated in the base of the furniture, that was designed to improved the heat transfer and solve problems of the passive systems. The advantage of the furniture systems is that they can be used in new construction and in existing building.

\subsection{Evolution in the different competitions}

Location. There have been five applications for floor and an equal number for ceilings; however, applications on the floor have been diminished, while the ceiling ones increase (see Fig. 5a). The teams do not justify the location of their systems, but can be seen that the trend to use the ceiling coincides with the appearance of new materials that integrate PCM and with that the recent applications are designed primarily to cool the space.

Type of application. In 2005, the first time in the competition using PCM, the four systems presented were assisted by fans or pumps, active elements. In the last competition only one of the five systems had active elements (see Fig. 5b). The appearance on the market from 2007 of panels or mats with PCM that can be easily integrated to the lightweight multilayer construction has contributed to this trend.

Type of PCM. Macro and micro encapsulated paraffin have been the PCM most used, followed by macro-capsules of hydrated salts (see Fig.5c). Nonparaffin organic compounds were used in 2005 by Team Canada and in 2009 by Penn State Team, which used a substance obtained from a residue of biodiesel.

Phase change temperature. The selected PCM have had different melting temperatures, depending on if the system was designed principally to avoid the overheating or the excessive cold. Generally, the fusion temperatures have been between $22^{\circ}$ and $27^{\circ} \mathrm{C}$; four teams with temperature between $22^{\circ}$ and $24^{\circ} \mathrm{C}$, four between $25^{\circ}$ and $27^{\circ} \mathrm{C}$. One case out of these ranges is the system presented by 
Rhode Island house, which had two thermal deposits: the cold, whose materials that change phase at $15^{\circ} \mathrm{C}$ and the hot, with a phase change at $58^{\circ} \mathrm{C}$.

Encapsulation. In the competition PCM has been integrated in many different ways, soaked by the material (only in 2005), macro-encapsulated, microencapsulated and molecular-encapsulated. The latter one allows a very high PCM concentration in a polymeric compound.
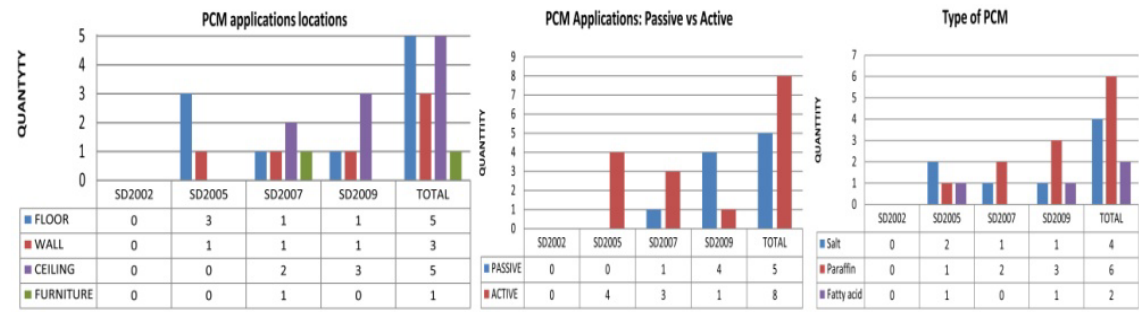

Figure 5: Location, application and PCM type charts.

\section{Conclusions}

The present review was focused on the latent heat thermal energy storage application in the Solar Decathlon houses. The fact that in this competition, which awards the thermal comfort and the energy efficiency, many teams incorporate PCM applications, demonstrates the use of these substances improves the energy performance of lightweight multilayer construction, as houses simulations shown. However, since the diversity of the houses and with only one week of monitoring, it is not possible to draw specific conclusions on the applications used. It would be necessary to monitor the houses for much time to be able to confirm the results of his simulations.

The Solar Decathlon competition has allowed universities around the world move forward in their research on the latent heat storage and integration of the PCM in light construction. Universities have moved from the experimental cells to build real houses, integrating the industry in this process.

In the past three competitions, innovative applications have been presented with organic and inorganic PCM, macro and micro encapsulations, passive or with the assistant of active elements, and taking advantage of the environment resources as a free-cooling or night radiation.

\section{References}

[1] Warner, C., Farrar-Nagy, S., Wassmer, M., Stafford, B., King, R., Vega Sanchez, S., Rodriguez Ubiñas, E., Cronemberger, J. \& Serra MariaTome, J., The 2009 Department of Energy Solar Decathlon and the 2010 European Solar Decathlon-expanding the global reach of zero energy 
homes through collegiate competitions. 2009 34th IEEE Photovoltaic Specialists Conference, Philadelphia, Pennsylvania, USA, 2009.

[2] SolarDecathlon Information. Available from: http://www.solardecathlon.gov

[3] Kuznik, F., Virgone, J. \& Johannes, K., In-situ study of thermal comfort enhancement in a renovated building equipped with phase change material wallboard. Renewable Energy 36, pp. 1458-1462, 2011.

[4] Zhu, L., Hurt, R., Correia, D., \& Boehm, R. Detailed energy saving performance analyses on thermal mass walls demonstrated in a zero energy house. Energy and Buildings, 41(3), pp. 303-310, 2009.

[5] Mehling, H. \& Cabeza, L., Heat and cool storage with PCM: An up to date introduction in to basics and applications. Springer -Verlag Berlin Heidelberg, 2008.

[6] Baggs, D. \& Mortensen, N., Thermal Mass in Building Design. BDP Environmental Design Guide. 2006.

[7] Cabeza, L., Castell, A., Barrenechea, C., Gracia, A. \& Fernández, A., Materials used as PCM in thermal energy storage in buildings: A review. Renewable and Sustainable Energy Reviews 15, pp. 1675-1695, 2011.

[8] Givoni, B., Effectiveness of mass and night ventilation in lowering the indoor daytime temperatures. Part I: 1993 experimental periods, Energy and Buildings 28, pp. 25-32, 1998.

[9] Shaviv, E., Yezioro, A. \& Capeluto, I.G., Thermal mass and night ventilation as passive cooling design strategy, Renewable Energy 24, pp. 445-452, 2001.

[10] Aroul Raj, A. \&Velraj, R., Review on free cooling of buildings using phase change materials. Renewable and Sustainable Energy Reviews 14, pp. 2819-2829, 2010.

[11] Barhydt, L., The North House as Responsive Architecture: Designing for Interaction between Building, Inhabitant, and Environment. Master of Architecture Thesis. University of Waterloo. Ontario, 2010.

[12] Team Ontario/BC., North House: Project Manual, 2009 Solar Decathlon Competition, Washington DC, 2009.

[13] Lauren B., The North House as Responsive Architecture: Designing for Interaction between Building, Inhabitant, and Environment. Master of Architecture Thesis. University of Waterloo, Ontario, 2010.

[14] Passini, M. \& Athienitis, A., Systems design of the Canadian Solar Decathlon House. ASHRAE Transactions, Vol. 112, Pt. 2, 2006.

[15] Rodríguez-Ubiñas, E., Cronemberger, J., Vega Sánchez, S. \& García Santos, A., Investigación de los materiales de cambio de fase en las universidades españolas. III Jornadas Sobre Investigación en Arquitectura y Urbanismo, Madrid, July 17, 2009.

[16] Neila González, J., Acha Román, C., Higueras García, E. \& Bedoya Frutos, C., Los Materiales de Cambio de Fase (MCF) empleados para la acumulación de energía en la arquitectura. Su aplicación en el prototipo Magic Box. Materiales de Construcción, Volume 58, No 291, 2008. 
[17] Lipinski, D., Winning Teams and Innovative Technologies from the 2005 Solar Decathlon, U.S. House of Representatives, Committee on Science, November 2, 2005.

[18] Agyenim, F., Hewitt, N., Eames, P. \& Smyth, M., A review of materials, heat transfer and phase change problem formulation for latent heat thermal energy storage systems (LHTESS). Renewable and Sustainable Energy Reviews 14, pp. 615-628, 2010.

[19] UPM Team, Casa Solar: Project Manual. 2007 Solar Decathlon, Washington, 2007.

[20] Medina, M., Phase-Change Structural Insulated Panels and Walls. United States Patent Application Publication. US2005/005982 A1, 2005

[21] Muruganantham, K., Phelan P., Horwath, P., Ludlam, D. \& McDonald, T., Experimental investigation of a bio-based Phase Change Material to improve building energy performance. Proceedings of ASME 2010 4th International Conference on Energy Sustainability, Phoenix, Arizona, USA, May 17-22, 2010.

[22] Witmer, L. Penn state 2009 Solar Decathlon Project Manual. Energy Analysis Results and Discussion, pp. 324-334, 2009.

[23] Team Germany, SurPlus House: Project Manual. Solar Decathlon 2009, Washington DC, 2009.

[24] Adell Argiles, J. M., The Black \& White House and its technical innovations. 5ta Expo Energía: Technical Workshop on Renewable Energy Innovative Technologies for the Building Sector. Lisbon, November, 2010.

[25] Agyenim, F., Hewitt, N., Eames, P. \& Smyth, M., A review of materials, heat transfer and phase change problem formulation for latent heat thermal energy storage systems (LHTESS), Renewable and Sustainable Energy Reviews 14, 2010.

[26] Hegger, M. (ed.), Sunny Times: Solar Decathlon House Team Deutschland 2007. Verlag Muller + Busmann KG, Wuppertal, 2008.

[27] Dammel, F., Steiner, L. \& Zeumer, M., Die Klimadecke des surPLUShome. Wissenschaftsmagazin der TU Darmstadt, pp. 42-47. Spring 2010.

[28] El khouli, S., Häuser als Kraftwerke: Solar Decathlon 2007+2009. Forum Energie Zurich, March 2009.

[29] UPM Team, Casa Solar: Construction drawings. 2007 Solar Decathlon, Washington, 2007. 